\title{
Analysis on the Creative Features of French Art Song in Impressionist Period
}

\author{
Yu Xiang \\ Music and Dance Institute \\ Qujing Normal University \\ Qujing, Yunnan, China 655011
}

\begin{abstract}
The French art song in impressionist period is a vital part of European culture, which has distinctive features in its creation. Lyrics are selected from the contemporary famous poets' poetry; music style is pure French impressionist features. The representatives of its creation are Debussy, Duparc, Fauré, etc.
\end{abstract}

\section{Keywords-impressionism; France; art song; creative feature}

\section{INTRODUCTION}

In the end of 19th century, influenced by literature of symbolism and impressionism painting, impressionist music was a new music style sprouting from European culture in Paris. The aesthetics, technique of expression, music texture and pursued artistic effect of impressionist music significantly diverge and differ from classicism and romanticism. The logo of impressionist music is to apply the fantasy molded by music to expressing the vague shadow and momentary music perception. Without the detailed story being the expressing content, impressionist music expresses the mood and sentiment interweaving light with color, the impressionist features of which are the obscure, misty, casual, occasional and visionary sound.

Art song is the lyrical solo prevailing in Europe in the turn of 18th and 19th centuries. With a strong expressiveness, complicated expressing means and composing skill as well as accompaniment playing an important role, art song mostly uses the famous poems as its lyrics and emphasizes the inner world of characters. As one of the highly featured music in romantic music, art song is especially composed for monophonic music and piano. When poetry blending with music while vocal blending with piano, accompanied by piano and used poetry as lyrics, art song is the solo for expressing the emotion and imagination of poetry with its music. [2] As an essential part of European culture, French art song has formed its own genre and prospered from the middle19th century to the early 20th century. The art song in France at that time was called "Melodie", which was firstly proposed by Berlioz. In the late 19th century, French art song stepped into a new creative period no matter in creative quantity or style, during which French vocal began to shatter the fetters of Italianization and formed its unique music style. The representatives of creating art song in this period included not only Debussythe founder of impressionist music, but Fauré who was known as French Schumann. Besides these people, Duparc, Ravel,
Poulenc and so on were also distinguished representatives of this period.

\section{THE LITERARINESS OF FRENCH ART SONG IN IMPRESSIONIST PERIOD}

\section{A. Lyrics and Poems}

Composers of French art song in the late 19th century preferred to use the literary works of contemporary poets of French Parnasse and Symbolism. Parnasse boldly adopted themes different from the past and describes exoticism to pursue the levelheaded selflessness art, laying more emphasis on the objective description on objects. Above all, the poems of Parnasse had musical rhythm, which was valued by composers. The symbolist poets sought after the musicality and gentle feeling of the verse on one hand, and pursued the spiritualization of literature and free verse as well. Being expert in blending poems and relevant art, the symbolist poets thought that the themes of poems like colorful sound and symphonic sentences were unnecessary to emphasize. Verlaine and Mallare were outstanding representatives of Parnasse and Symbolism. In the early days, they represented Parnasse. In 1880, they created Symbolism. In their works, they no longer took the concrete human character as themes of description, but focused on the natural scenery and its impressions on man. Highly appreciated by Debussy and Fauré, their poems had a nature which was performed in its full measure by art song composers. Fauré used poems of Verlaine in his Clair de Lune as early as 1887 , and adopted seventeen poems of Verlaine to compose in his lifelong art song creation. The art songs of Debussy mostly adopted the poems of Baudelaire, Verlaine, Mallare and so on as lyrics. For instance, Debussy used Verlaine's poems from 1890 to 1904 to compose Trois Mélodies, La Merest Plus Belle, Le Son Cors Affligé and L 'Échelonnement des Baies; in 1892, Debussy composed or recomposed art songs by using verses of Verlaine, in which En sourdine, Fantoches and Clair de Lune were included in Fêtes Galantes Set 1. In 1904, Debussy created two songbooks for Madame S. Pataco. One songbook was recomposed for Verlaine's Fêtes Galantes, in which were Les Ingénus, Le Faune, Colloque Sentimental, etc. The total songs that Debussy used poems of Verlaine were eighteen; Debussy also used the works of Mallare and Baudelaire to create such as Poèmes de Baudelaire, Poèmes de Stéphane Mallarmé, etc. Duparc in impressionist music period was another composer 
adopting poems of Symbolism in art song creation. The essence of Baudelaire's verses was perfectly displayed by Duparc. The French critic Aubry thought that the art songs of Duparc derived from Baudelaire's verses comprehended Baudelaire's spirit better than that of Debussy. For instance, L' invitation au Voyage and La Vie Anterieure-Duparc's last art song were two typical examples of cooperating Duparc and Baudelaire's poems.

\section{B. Lyrics and Music}

Using the musical poems to create art song has always been the favorite of the composers whose motive power is the direct emotion of poems. Early in ancient Greece, people have formed the aesthetic about poetic music namely "take poem as a priority and music as a supplement". While, the poems in the period of Romanticism and Impressionism attached particular attention to the rules of rhyme scheme, which just in line with then music style provided creative materials for composers. The creative works of such impressionist poets as Baudelaire, Verlaine and Mallare stimulated enthusiasm of Fauré, Duparc and Debussy and inspired them to create art songs. The language of their poems had a distinctive rhythm, in which words arrangment, cadence and length all embodied the poems' being-singed nature. The language features of their poems offered significant referrence for tone arranging, rhyme designing and tonality distributing of art songs. As the representative work of musical poems and selected from Verlaine's Romances Sans Paroles, Il Pleure Dans Mon Coeur was included in song-cycle Ariettes Oubliees which had the lyrics with good music and rhythm and four stanzas and sixteen lines. The first and third stanzas rhymed babb while the second and forth stanzas rhymed abaa ("a" denoted masculine rhyme namely the word's last rhyme was a soundless "e", others used "b"to mark the rhymes). See the following "Table I".

\begin{tabular}{|l|l|l|l|}
\hline First Stanza & Second Stanza & Third Stanza & Forth Stanza \\
\hline Coeur & Pluie & Raison & Peine \\
Masculine & Feminine & Masculine & Feminine \\
Rhyme & Rhyme & Rhyme & Rhyme \\
\hline Ville & Toits & ÉCoeure & Pourquoi \\
Feminine & Masculine & Feminine & Masculine \\
Rhyme & Rhyme & Rhyme & Rhyme \\
\hline Langueur & Ennuie & Son & Haine \\
Masculine & Feminine & Masculine & Feminine \\
Rhyme & Rhyme & Rhyme & Rhyme \\
\hline
\end{tabular}

TABle I. The Rhymes ArRangment of Il Pleure Dans Mon COEUR

Through close observation of Il Pleure Dans Mon Coeur, it can be found that the typical characteristics of Verlaine's poems namely emphasizing verses' musicality is well embodied by the measures of rhyming binomes, rhyming the same and same words. In the poem, the places where rhyming binomes occur are "pleure" and "Coeur" in the first sentence of first stanza, "bruit" and "pluie"in the second sentence of second stanza, " coeur" and "s"écoeure" in the second sentence of third stanza, "Sans" and "Sans" in the third sentence of forth stanza. Rhyming the same is illustrated in the above table. The places where same words occur are "mon Coeur" in the first and forth sentences of first stanza, "bruit" and "la pluie" in the first and forth sentences of second stanza, "sans raison" in the first and forth sentences of third stanza, "peine" in the first and forth sentences of forth stanza.

\section{The CREATIVE FEATURES OF Music}

A. The Composers in the Impressionist Period Boldly Broke the Bondages of the Traditional Mode and Tonality and Applied Combination of Medieval Modes, Major and Minor Modes

In the song-cycle Histories Naturelles, Ravel used Lydian mode and Aiolia mode; having a strong enthusiasm about Spanish folk music, Ravel often applied Spanish mode to his works such as L' heure Espagnole and Habanera Vocal Music; eight tone mode appeared in Ravel's works too, but Ravel used it episodically when more lyric mood was needed or confirm music conflict and contradiction; influenced by the music in World Exposition, Ravel applied pentatonic mode to his works, whose strong oriental characteristics richly varied its harmony. He often drew creative materials from exotic music such as Chinese and Turkish music to establish harmony of various styles. For example, in his song-cycle Histories Naturelles, Ravel used F Gong Diao tune to describe peacock. In creating art song, Debussy also preferred such mode techniques as diatonic scale, pentatonic mode and medieval mode to achieve the bizarre effects of impressionist music. Having a lot augmented and diminishedintervals, diatonic scale built a drifting feeling for music structure, which was exactly wanted effect of Debussy. Therefore, in his works, Debussy often used diatonic scalesometimes episodically and sometimes wholly.

\section{B. The Composers in Impressionist Period Attached Special Attention to Harmony, Texture and Orchestration's Color}

Placing harmony in a vital part, composers in impressionist period used chord to create the mood which music tried to express. Breaking the normal of connecting tonal inside chords, chord served a function as destroying tonality rather than strengthening it. Frequently appearing in the harmony of many works of this period, triad which didn't has tonal relations generated vague tonality and a feeling of instability and hesitation between tonalities. Breaking the logical system of traditional harmony, harmony arrangement used parallel fifths, ninth chord, derived chord, whole-tone chord constituted by whole tone in diatonic scale, mode scale, Oriental pentatonic scale and so on to gain rich harmonic color for the accompaniment of art song. Chromatic technique was also the idiomatic music technique, typical used in the C'est L'extase of Ariettes Oubliees, Duparc's Dernières Volontés. Fascinated in chord, Debussy made bold innovation in scale of art song in his early creative days. In creating art song, Debussy usually used chord as independent unit at his will, and especially used the dissonant chord to achieve the particular impressionist effects, which was a typical technique in creating art song of this period. Continuously using Fweth, major third, ninth, DO$\mathrm{RE}$ and seven commonly occurred in the works of this period. Composers also pursued free rhythms in creating and used various rhythms to express music conflicts. Not good at miles and miles long melody and grand form, art song in impressionist period preferred to pursue short and irregular exquisite sound pattern and gentle curves. As a special 
harmonic technique, basso continuo was highly appreciated by composers in impressionist period, which was applied skillfully by Duparc to his accompaniment melody. In composing the harmony of accompaniment, he allowed basso continuo to continue in dozens of sections. L' invitation au Voyage was a typical example, in which Duparc used continuous basso continuo together with the preceding several parts of chord to create a sea-like dream scene. So was La Vie Anterieure and Au pays où se fait la guerre.

\section{The Proper Application of Musical Terms}

Another characteristic of composers' creating in impressionist period is their proper application of musical expression terms. Getting rid of the traditional composing techniques, the impressionist music works introduced new techniques to make itself more complicated in structure, rich in mode and tonality and various in chord and texture; not as direct as before, the content expressed in music tried to present a vague and momentary music perception by molding fantasy. No longer describing the detailed story, impressionist music expresses the mood and sentiment interweaving light with color. These features made impressionist art song being wispy from content to technique, which brought certain difficulties for singers and analyst. However, composers' musical terms often appeared timely to express theirmusic intentions. For example, in C'est L' extase of Ariettes Oubliees, Debussy began to require "Lent et caressant" in its speed namely being slowly, gently and fondled-like, "PP" in force namely being feeble. The work's expression from eleventh to seventeenth sections significantly differed with that of the preceding. From here, variation appeared both in emotion and music itself, which embodied in his using of expression terms, music notation and so on. In melody, Debussy required "un pocomosso" (with a bit of excitement) namely keeping each sound. The melody voice from twentieth to forty-third sections was required by composers to be animato gradually (poco a poco animato), to be more excited in emotion expressing and broad in music.From twenty-forth section, part of the melody was required to ascend chromaticism and the accompaniment was required to descend chromaticism, both of which were required to be dimimuendo in volume so as to work with the mood expressed by lyrics.The twenty-ninth section was required to be sempredolcissimo (keeping sweet and soft). From fortieth to forty-third sections, vocal melody was required to be crescendogradually till the only " $m f$ " in the work. Combining music material group and lyric analysis, it was easy to find that the composer was trying to build a joyous mood. The forty-forth to fifty-second sections were the third part of tape representation. The melody of forty-forth section descended and the work force gradually reduced from " $\mathrm{mf}$ " to "pp" then to "ppp", and to be murmured in the end, which kept throughout the work. From this work, it could be seen that Debussy took great pains in musical terms, which illustrated the significance of musical terms in art songs of impressionist period.

\section{Piano Accompaniment}

Piano accompaniment was indispensible part of French art song in impressionist period which was the synthesis of melody and accompaniment. Although rarely repeating the melody voice, piano accompaniment still was a vital tool in sketching impressionist mood. Piano accompaniment foiled and enriched songs' content by such musical techniques as various sound patterns, different harmony, richpinaowork, changing speed and controlling timbre. It could foreshadow music theme by prelude, connect music's different parts by interlude and finish molding the theme by coda. Fauré could use piano's expressive force skillfully in the accompaniment of art song to make the melody and accompaniment melting together into an organic whole. When composing piano accompaniment, Fauréfully excavated the expressive force of harmony and used simple but exquisite texture whenever possible. For the purpose of increasing the artistic appeal of art songs, Fauré applied various changing chord, ninths and so on to his accompaniment composing. For instance, when composing the accompaniment of Clair de Lune, Fauré used flowing broken chord to support the polished and indistinct vocal melody; singing voice and piano accompaniment melted together; even the Lydian mode was applied to expressing the wonderful-life mood that lyrics of poem had; fluent singing accompanied by piano crested a vague and serene scene. Especially in its prelude, piano accompaniment foreshadowed music emotion by the minuet-style playing.

As the typical representative of impressionist music, Debussy emphasized the function of sound and timbre in composing piano accompaniment. Of great significance to Debussy, harmony was an essential tool to depict artistic conception such as to describe nature, pour feeling, express emotion, foil mood, stimulate senses, etc. Debussy's piano accompaniment was individualistic. Frequent and subtle modulation, fresh rhymes and texture, as well as the unsolved chord sequence and harmony comparison were Debussy's techniques in depicting poems, which often created the indistinct mood of poems and redeployed audience's senses and emotion.[4] When composing the piano accompaniment of Scènes au Crépuscule, Debussy applied such flat chord in prelude as dropping seven minor triad to hinting the melancholy in music. His harmony usedin piano accompaniment was to describe the warm images when the breeze was blowing the rye under the setting sun and the texture of harmony was mainly broken chord. When the song was ending, the continuous arpeggio - ninth chord in piano accompaniment foiled the song's sentiment- "we are going toward tomb".

Duparc's art songs were mainly descriptions of beautiful love and melancholic emotion. He preferred to apply basso continuo to piano accompaniment of his works. The melody of the singing voice was short and exquisite, which could possibly be the main motive of music with the similar rhymes running through it. Chromatic progression was Duparc's mostly skillful technique of expressing music. For instance, in the piano accompaniment of Phidyle, the serene and soft scene was depicted by accompaniment and singing melody. The rhymes of accompaniment in his works were vivid; the characteristic chromatic progression and rich harmony alternated with major-minor keynote. 


\section{REFERENCES}

[1] Thompson (America). Debussy: Man and Artist [M] translated by Zhu Xiaorong and Zhang Hongmo. Beijing: Central Conservatory of Music Press, 2006 (1): 256.

[2] Roger Kamien(America). Music: An Appreciation [M] translated by Xu De. Haikou: Hainan Publishing House, 2004:278.

[3] Li Rong. See French Art Song from Fauré and Debussy [D].Capital Normal University, 2005.

[4] Wang Dayan. Introduction to Art Songs [M]. Shanghai: Shanghai Music Publishing House, 2009 (2): 366. 